\title{
Evaluating the Potential for Development of Vegetable Nursery Industry: Analysis in an Important Vegetable Region in Italy
}

\author{
Giuseppe Timpanaro, Arturo Urso, Carlo Prato and Vera Teresa Foti \\ Department of Agri-Food and Environmental Systems Management (DiGeSA), \\ University of Catania, Via S.Sofia, 98-10095123 Catania, Italy
}

\author{
Article history \\ Received: 1-01-2014 \\ Revised: $15-4-2015$ \\ Accepted: 15-5-2015 \\ Corresponding Author: \\ Giuseppe Timpanaro \\ Department of Agri-Food and \\ Environmental Systems \\ Management (DiGeSA) \\ University of Catania, Via S. \\ Sofia, 98-10095123 Catania, \\ Italy \\ Tel: +390957580305 \\ Email: giuseppe.timpanaro@unict.it
}

\begin{abstract}
Nursery industry has a considerable importance in the value chain' building of vegetable companies. Its importance increases in a country like Italy, where vegetable productions in open field and in greenhouse contribute significantly to the creation of income and employment and to the socio-economic support of entire geographic areas. However, this sector is underpowered, if compared to the potential expressed by the vegetable production, considering that technical, economic and market literature suggests the opportunity to extend the use of transplantation as an alternative to the direct seeding in order to achieve environmental and commercial benefits. This work was both the result of a meta-analysis and a direct survey and aims to determine an estimate of demand of nursery industry in Sicily, a region that intercepts approximately $31 \%$ of national investments in protected cultivation and provides the basis for evaluating the activation potential of new investments, considering technical legislative and market aspects and the supply chain integration.
\end{abstract}

Keywords: Plant Nursery, Seeding and Nursery Activities, Geographic Information System (GIS)

\section{Introduction}

The production of vegetable plants is intimately connected to the territory in which it takes place, both in the upstream and in the downstream plant nursery production (Bianco and Pimpini, 1990). Upstream production includes all support activities ranging from the provision of means of production (seeds, plant protection products, protective structures, etc.), to the logistics, technical assistance and support services (eg. the issuing of phytosanitary certificates). Downstream production refers to the users of the seedlings, mainly represented by growers who want to achieve full production in the open field or in the greenhouse. The nurseries, therefore, assume an important role within the vegetable supply chains, influencing the possibilities of development and generation of added value for all the figures involved along the value chain, which is why an accurate knowledge of their geographical location becomes of particular interest (Schlimme, 1995).

The vegetable production, in open field and in greenhouse, is widespread throughout Italy (FAOSTAT, 2012) with a more concentration in some regions such as
Campania, Emilia Romagna and Sicily and, to a lesser extent, in Lombardy, Apulia, Veneto and Lazio (ISTAT, 2013). It represents the $14.2 \%$ (million EUR 7,088.8) of the whole production of Italian agriculture in 2012 (million EUR 49,0936.4, basic prices) and is really varied in terms of quantity and value. In 2012, some important components were represented by tomatoes (about 6 million tons and over 1 billion Euros of production), kitchen gardens (over 1.8 million tons and $€$ 694 million), potatoes (1.6 million tons and€ 663 million), lettuce (482 thousand tons and $€ 482$ million), artichokes (478 thousand tons and $€ 424$ million), zucchini (504 thousand tons and $€ 383$ million) and fennel (464 thousand tons and $€ 378$ million), along with many other species (INEA, 2013).

Plant nursery is placed in the same areas in which vegetable production is very widespread. By limiting the comparison to the data of ISTAT General Census of Agriculture, in Italy the coverage ratio (plant nursery/vegetable cultivation) is equal to 1 plantnursery company every 22 vegetableproduction companies, that is 1 ha of plant nursery every 50 ha of vegetablecultivation. 
These reports suggestgreat opportunitiesfor an expansion of plant nursery production at national level, which is considered essential not only to ensure a wider coverage degree of the current demand for vegetable propagation materials, but also to encourage the use of this propagation system and to enfranchise the producing regions from the import of these materials from extraregional territories. To support this thesis, we can refer, on the one hand, to the numerous technical experiments of replacing the seeding with the transplant (supported by the technical evolution of transplanters, cultivation media, substrates andplant nursery technique, etc.) and to the opportunities in terms of costs, reduction of the cycle of cultivation and of the production planning; on the other hand, to the growing demand of food production in terms of quality and quantity (agronomic, sensory, hedonistic, healthy, industrial, etc.), of safety of food and environment, of resistance to pathogens and adverse environmental conditions, optimization and standardization, efficiency and economy, quality and traceability of the entire process, starting from the upstream supply chain activities, including the plant nursery (Zinati, 2005) (Although breeding of plants to transplant constitutes a service partly done within the same farms, in the total absence of specialization and marginally compared to the overall activities of the company, horticultural operators are well aware that the construction of a modern and integrated supply chain within the food system can take advantage of the use of external structures with a high level of specialization).

The modern plantnursery activities are very complex and characterized by: Intensive cultivation schemes realized by means of capital assets and working capital; manufacturing processes, high standard of integration and coordination, relationships with raw material market and final market, no longer confined to the local level but targeted towards inter-regional or national scale. This organizational complexity, associated with the large number of production cycles (the sowing is always carried out in multi-hole containers, under greenhouses, to monitor the entire process and ensure the qualitative/quantitative and phytosanitary result) and the simultaneous presence within the structure of a variety of plant nursery areas able to perform the stages of the production process (collections for mother plants, seedlings, greenhouse cultivation, etc.), with consequent fragmentation of farmland, make it difficult to assess the vegetable area that can be covered by the potential production of regional nurseries. For research purposes, the problem may be looked at both from the side of the plant nursery (supply), to determine the potential production of seedlings to be offered on the market and from the side of the vegetable company (demand), which wants to expand the acquisition on the market of base propagating material. Literature demonstrates the interest in knowing the organizational structures of plant nurseries at a local level, also through the implementation of specific monitoring programs (Hodges et al., 2008; Acquaah, 2008).

These issues become relevant for Sicily, a region that intercepts the $9.3 \%$ of national plant nursery, the $10 \%$ of vegetable areas and the $31 \%$ of Italian vegetable greenhouses, in which the aforementioned coverage ratio (plant nursery/vegetable cultivation) is equal to 1 plantnursery company every 104 vegetable companies, that is 1 ha of plant nursery every 221 ha ofvegetable cultivation or every 73 ha ofvegetable greenhouses.

In light of the foregoing, was attempted an estimate of the potential of vegetable nursery activities for expanding their production, to meet the growing regional demand for these products, through an empirical analysis, in order to investigate the relationship between the regional plant nursery production and the determinant factors and to identify a model that could explain the propensity of nurserymen to increase their vegetable cultivation areas.

\section{Materials and Methods}

Our hypothesis is that every plant nursery production company is potentially interested in increasing its production activities, including with the use of new investments, but this enlargement is influenced by different factors. On the one hand, there are strictly structural and organizational factors that may affect the company's activities, on the other hand there are more strictly economic aspects, also linked to the demand for seedlings. From the structural point of view, some significant estimates linked to the level of automation and mechanization of the plant nursery can be traced in the work of Posadas et al. (2008). The potential demand for seedlings, instead, can be conditioned by the commercial actions carried out by the seed industry (such as the use of trademarks or the testing of new hybrid varieties required by the market, etc.), or by the growers' expectations in terms of technical, environmental and commercial benefits that could derive from a wider use of transplantation.

An attempt to determine the production capacity of the plant nursery company can be found in the work of Knowlera and Barbier (2005) and Barbier et al. (2011), while other works considered commercial aspects (Crane Barahona, 1996; Hardenburg et al., 1990).

Other variables may affect the production potential of the plant nursery company, but they are considered of little relevance to our study and therefore not included. To be more precise, the factors taken into account in the model are expressed in the following equation:

$$
\mathrm{S}_{\mathrm{n}}=\mathrm{f}\left(\mathrm{T}_{\mathrm{n}}, \mathrm{E}_{\mathrm{n}}, \mathrm{A}_{\mathrm{n}}\right)
$$


Where:

$\mathrm{S}_{\mathrm{n}}=$ Regional plant nursery surface in evaluation

$\mathrm{T}_{\mathrm{n}}=$ Set of variables related to technical aspects (location, proximity to the production system, exposure of soils, water resources, species and varieties multiplied; seed provenance; crop cycles achieved; cultivation density per species and varieties; utilization level of technical means; possibility of local supplying; types of structures by dimension, cubic capacity, technologies and systems, degree of automation, etc.)

$\mathrm{E}_{\mathrm{n}}=$ Set of variables related to economic aspects (time of company's foundation; degree of integration with the multinational seed companies; reference market; reputation of the seed company with whom the plant nursery works; royalties to be paid; contractual guarantees; trademarks and advertising strategies; links with local organizations and research institutions, etc.)

$A_{n}=$ Set of variables related to environmental issues (regulatory restrictions on genetic and health questions; certification of marketed plants, product quality, etc.)

Since the start of a plant nursery activity presupposes rather high land capital investments (structures) and working capital investment (plants), we have assumed an increase in the nursery production at existing facilities in the short term. Previously, we analyzed the spatial distribution of these structures using a meta-analysis of official information available by resorting to Geographic Information System (GIS), which is a useful tool to represent a good approximation of the spatial distribution of different information available on the territory (Borrough, 1986). The GIS environment allows, in fact, to store, manage, analyse and represent geo referenced qualitative and quantitative data, in order to use the maximum of available information and allow the intersection of all the data in a single reference system to obtain additional information through overlay operations (Malczewski, 2004). The use of GIS-based tools of representation and data analysis is an important support to guide policy makers and institutional sectors even in the case of plant nursery and vegetable seed production (Malczewski, 1999).

After completing the meta-analysis and defined the location of plant nursery structures, we started the second part of the research, surveying:

- The location choices of operating or service structures, the positioning, sizing and operational management of infrastructure, the representation and monitoring of cultivated areas and greenhouses

- The estimates of seasonal production, of product availability and the consequent price

- The control of vulnerable territories, the monitoring and environmental impact assessments
- The zoning of certified quality productions, as well as to the definition of basins of influence and areas of interest of the real or potential market of a vegetable product

For this purpose we developed a direct detection of businesses nurseries, for a total of 100 plots planted. Using this sample, a multiple linear regression analysis was performed, testing a model summarized by the following equation:

$$
\begin{gathered}
S_{n}=\alpha+\beta 1 \text { seed used }+\beta 2 \text { perceived quality of final } \\
\text { product }+\beta 3 \text { phytosanitary and geneticconstraints }+ \\
\beta 4 \text { legislation }+\beta 5 \text { degree of integration and market }+ \\
\beta 6 \text { characteristics of nursery }+\varepsilon
\end{gathered}
$$

In particular:

- $\quad$ Seed used was evaluated in quantity $(q / h a)$; the perceived quality was measured in relation to the degree of germination and engraftment (n. seedlings in $\mathrm{m}^{2}$ )

- Constraints genetic and phytosanitary (royalties paid)

- Legislation is measured in terms of good agricultural practices (planting density, the degree of integration and trade is related to the existence or not of cultivation contracts (yes-no, no.)

- Business characteristics are nurseries were bound to the surface invested (ha)

Data collected were previously subjected to standardization with classical methods, in order to eliminate the distortions resulting from the combined use of information that have different ranges of variation and measurement scales.

\section{Results}

\section{Analysis of Current State of Plant Nursery}

ISTAT General Census of Agriculture distinguishes the so-called "Nurseries" by the "Seedling Nursery", where the first category includes all "activities involving the cultivation of woody agricultural and forestry plants intended for transplantation, including fruit nursery, ornamental plants as well as grapevine rootstock mother plants and vine plants" (Forest nurseries intended for forest growing and non-woody species held for sale or for company needs are excluded from this category. This category is divided into 3 main groups: "fruit nurseries", "ornamental plant nurseries" and "other nurseries), while the second category includes the "non-woody species seedlings in the early stages of development held for sale to be transplanted" (The nurseries of our interest are included in this category and they are divided in: "horticultural 
seedling nurseries", "floriculture and ornamental seedling nurseries" and "other seedling nurseries"), as happens in the horti-floriculture of our interest.

At a national level, according to ISTAT (Table 1), there was a contraction of the production units in the inter-census period $2000-2010$ (-7\% for nurseries and $14 \%$ for seedling nurseries) and an expansion of their investments $(+49 \%$ for the first category and $+20 \%$ for the latter), although lower in the case of seedling nurseries. The main regions involved in plant nursery activity are Lombardy, Tuscany and Veneto; we must also add the Southern Italy areas in which vegetables are traditionally produced, in open field and in greenhouse.

In 2010 , there were 1,142 plant nursery structures in Sicily, covering a total area of approximately 1,705 hectares, variously distributed between "nurseries" (72\% of the companies on $78 \%$ of the area) and "seedling nurseries" ( $28 \%$ of the production units and $22 \%$ of investments).

We observed an interesting evolution dynamic in Sicily, with a partial reversal of the relative importance of the two categories considered. In fact, while the "nurseries" in the inter-census period suffered a $40 \%$ reduction of the production units (from 1,378 to 822 nurseries) and a $7 \%$ reduction of the areas (approximately from 1,421 to 1,322 acres), the so-called "seedling nurseries" showed a dynamic development of particular intensity, with a $15 \%$ increment of the production units (from 278 to 320 ) and a $198 \%$ increment of covered areas (from a little more than 128 acres to over 382 acres).

The dynamics of the average sizes clearly shows an evolutionary trend towards a concentration of the phenomenon, with a siting of the units in the most suitable areas, with high levels of specialization, productivity and technical-economic efficiency, in relation to the availability of modern technology, often centred on species and varieties of international or greater interest in the market.

In the case of seedling nursery, an increase in the relative importance of Sicily must be reported, with the $9.3 \%$ of national companies and the $10.7 \%$ of national areas in 2010 and with growth rates of 35 and $149 \%$ in the period 2000-2010.

For comparative purposes and to deepen the structural analysis of plant nursery production in Sicily, we used some information from the Centre for Plant Diseases of the Regional Board of Agriculture and Food, a body entrusted by the State (Decree of 6 March 1989) through which the Region operates for certifications, plant health checks and research on plant defence techniques. In addition, this Centre supervises all regional companies that produce, market or import plants, seeds and wood for agricultural, industrial and commercial purposes, as well as nurseries and companies registered in the Official Register of Producers (DA 4870 of 18 December 2000) that sell plant material with "high risk".
According to the data, in 2013, Sicilian nurseries authorized to produce vegetable seedlings were 83 and the area concerned was 110 hectares (Table 2). The phenomenon was more concentrated than in 2010 because the structures had been reduced by $39 \%$ and the surfaces by $21 \%$. The provinces where there was the greatest concentration of investments were Ragusa, Catania and Syracuse; in the same areas, there were the nurseries with a wider average area (1.69 hectares for Catania, 1.66 for Ragusa and 1.59 for Syracuse, compared to a regional average area of 1.33 hectares).

In summary, analysing the data of Plant Protection Service, the following characteristic features of the sector in Sicily emerge:

- Particular orientation to production and/or marketing, with a marginal production function conditioning the organizational, managerial and technical-productive assets

- Variable average size of the company between one province and another and observed intense processes of specialization, marked by the contraction of companies and the increase in plant nursery areas

- Development of the sector bound to legislative, technical-productive, technological, entrepreneurial and market constraints, affecting even more the organic plant nursery

\section{Geo-Referenced Analysis}

The vegetable production is present in all provinces (Viani, 1929), with different roles. In terms of extension, Ragusa prevails with over 9,000 hectares, followed by Syracuse with nearly 5,000 acres and then Palermo and Agrigento with 3,500 ha, Catania and Caltanissetta with 3,000 hectares. The inter-census trend is positive for all provinces, except for Messina which lost about 600 hectares in 10 years (Table 3 ).

With reference to the cultivation methods, the most interesting data concern the cultivation in greenhouse: in fact, this is the variable with the greatest impact in terms of productivity but also in relation to the use of fertilizers, plant protection products and consumption of water, plastic (hoses and covers) and polystyrene. The cultivation of vegetable crops in greenhouse covers more than 10,000 hectares in Sicily, equal to about one-third of the total vegetable production (Table 4).

The situation is not uniform, indeed there are provinces where crops are grown mainly in the open filed (Palermo, Catania, Messina, Enna) and others where cultivation in greenhouses or tunnels reaches very high percentages, like in Caltanissetta (29\%), Syracuse (33\%), Agrigento (39\%), Ragusa (62\%). 
Giuseppe Timpanaro et al. / American Journal of Agricultural and Biological Sciences 2015, 10 (2): 74.82 DOI: 10.3844/ajabssp.2015.74.82

Table 1. Size of nurseries industry according to official database $(*)$

\begin{tabular}{|c|c|c|c|c|c|c|}
\hline \multirow[b]{3}{*}{ Feature } & \multicolumn{2}{|c|}{2000 (a) } & \multicolumn{4}{|c|}{$2010(\mathrm{~b})$} \\
\hline & \multirow{2}{*}{$\begin{array}{l}\text { Farms } \\
\text { n. }\end{array}$} & \multirow{2}{*}{ Area } & \multirow{2}{*}{$\begin{array}{l}\text { Farms } \\
\text { n. }\end{array}$} & Area & \multicolumn{2}{|c|}{ Differences (a-b) } \\
\hline & & & & ha & Farms & Area \\
\hline Italy & & & & & & \\
\hline Nurseries & $\begin{array}{l}6.78 \\
100\end{array}$ & $\begin{array}{l}12.178,73 \\
100\end{array}$ & $\begin{array}{l}6.311 \\
93\end{array}$ & $\begin{array}{l}18.093,93 \\
149\end{array}$ & -469 & $5.915,2$ \\
\hline Seedling nurseries & $\begin{array}{l}4.026 \\
100\end{array}$ & $\begin{array}{l}2.966,52 \\
100\end{array}$ & $\begin{array}{l}3.454 \\
86\end{array}$ & $\begin{array}{l}3.564,64 \\
120\end{array}$ & -572 & 598,1 \\
\hline Total & $\begin{array}{l}10.806 \\
100\end{array}$ & $\begin{array}{l}15.145,3 \\
100\end{array}$ & $\begin{array}{l}9.765 \\
90\end{array}$ & $\begin{array}{l}21.658,6 \\
143\end{array}$ & -1.041 & $6.513,3$ \\
\hline Average surface [ha] & & & & & & \\
\hline $\begin{array}{l}\text { - nurseries } \\
\text { - seedling nurseries }\end{array}$ & & $\begin{array}{l}1,80 \\
100 \\
0,74 \\
100\end{array}$ & & $\begin{array}{l}2,87 \\
160 \\
1,03 \\
140\end{array}$ & & \\
\hline Sicily & & & & & & \\
\hline Nurseries & $\begin{array}{l}1.378 \\
100\end{array}$ & $\begin{array}{l}1.420,94 \\
100\end{array}$ & $\begin{array}{l}822 \\
60\end{array}$ & $\begin{array}{l}1.322,10 \\
93\end{array}$ & -556 & $-98,8$ \\
\hline Seedling nurseries & $\begin{array}{l}278 \\
100\end{array}$ & $\begin{array}{l}128,47 \\
100\end{array}$ & $\begin{array}{l}320 \\
115\end{array}$ & $\begin{array}{l}382,67 \\
298\end{array}$ & 42 & 254,2 \\
\hline Total & $\begin{array}{l}1.656 \\
100\end{array}$ & $\begin{array}{l}1.549,4 \\
100\end{array}$ & $\begin{array}{l}1.142 \\
69\end{array}$ & $\begin{array}{l}1.704,8 \\
110\end{array}$ & -514 & 155,4 \\
\hline Average surface [ha] & & & & & & \\
\hline - nurseries & & $\begin{array}{l}1,03 \\
100\end{array}$ & $\begin{array}{l}1,61 \\
156\end{array}$ & & & \\
\hline - seedling nurseries & & $\begin{array}{l}0,46 \\
100\end{array}$ & $\begin{array}{l}1,20 \\
259\end{array}$ & & & \\
\hline
\end{tabular}

(*) ISTAT database, Rome

Table 2. Vegetables nursery industry in Sicily: comparison between ISTAT database and PPS database (*)

\begin{tabular}{|c|c|c|c|c|c|c|}
\hline \multirow[b]{2}{*}{ Province } & \multicolumn{2}{|c|}{ Farms (n.) } & & \multicolumn{2}{|c|}{ Surface (ha) } & \multirow[b]{2}{*}{ Var. $\%$} \\
\hline & $\begin{array}{l}\text { ISTAT* } \\
2010\end{array}$ & $\begin{array}{l}\text { PPS** } \\
2013\end{array}$ & Var. \% & $\begin{array}{l}\text { ISTAT* } \\
2010\end{array}$ & $\begin{array}{l}\text { PPS** } \\
2013\end{array}$ & \\
\hline Trapani & 11 & 26 & 136,4 & 12,91 & 11,55 & $-10,5$ \\
\hline Palermo & 23 & 19 & $-17,4$ & 15,53 & 5,60 & $-63,9$ \\
\hline Messina & 18 & 5 & $-72,2$ & 10,98 & 2,22 & $-79,8$ \\
\hline Agrigento & 10 & 18 & 80,0 & 7,51 & 12,79 & 70,3 \\
\hline Caltanissetta & 6 & 2 & $-66,7$ & 6,93 & 1,28 & $-81,5$ \\
\hline Enna & 9 & 2 & $-77,8$ & 7,79 & 0,82 & $-89,5$ \\
\hline Catania & 14 & 21 & 50,0 & 11,63 & 35,48 & 205,1 \\
\hline Ragusa & 32 & 25 & $-21,9$ & 44,59 & 41,60 & $-6,7$ \\
\hline Siracusa & 13 & 10 & $-23,1$ & 20,68 & 15,83 & $-23,5$ \\
\hline Sicilia & 136 & 83 & $-39,0$ & 138,55 & 110,02 & $-20,6$ \\
\hline
\end{tabular}

(*) ISTAT database, Rome; (**) Plant Protection Service, Palermo

Table 3. Vegetable production trend in Sicily and Italy $(*)$

\begin{tabular}{|c|c|c|c|c|c|c|}
\hline & Farms (n.) & & & & Area (ha) & \\
\hline Province & 2000 & 2010 & Var. \% & 2000 & 2010 & Var. \% \\
\hline Trapani & 3.551 & 1.449 & $-59,2$ & $2.163,00$ & $2.192,00$ & 1,3 \\
\hline Palermo & 4.954 & 2.268 & $-54,2$ & $2.797,00$ & $3.438,12$ & 22,9 \\
\hline Messina & 7.007 & 1.067 & $-84,8$ & $1.103,80$ & 448,45 & $-59,4$ \\
\hline Agrigento & 3.949 & 1.452 & $-63,2$ & $3.331,12$ & $3.539,16$ & 6,2 \\
\hline Caltanissetta & 1.903 & 1.235 & $-35,1$ & $2.321,56$ & $3.011,56$ & 29,7 \\
\hline Enna & 572 & 511 & $-10,7$ & 361,02 & 812,90 & 125,2 \\
\hline Catania & 1.25 & 996 & $-20,3$ & $1.615,11$ & $2.974,14$ & 84,1 \\
\hline Ragusa & 5.054 & 3.869 & $-23,4$ & $7.516,10$ & $9.155,66$ & 21,8 \\
\hline Siracusa & 1.364 & 1.283 & $-5,9$ & $2.921,54$ & $4.992,07$ & 70,9 \\
\hline Sicily (a) & 29.604 & 14.13 & $-52,3$ & $24.130,25$ & $30.564,06$ & 26,7 \\
\hline Italy (b) & 265.558 & 111.682 & $-57,9$ & $259.295,54$ & $299.681,67$ & 15,6 \\
\hline$\%(a) /(b)$ & 11,1 & 12,7 & & 9,3 & 10,2 & \\
\hline
\end{tabular}

(*) ISTAT database, Rome 
Giuseppe Timpanaro et al. / American Journal of Agricultural and Biological Sciences 2015, 10 (2): 74.82 DOI: $10.3844 /$ ajabssp.2015.74.82

Table 4. Production area for horticulture under protection in Sicily and in Italy $(2010)(*)$

\begin{tabular}{lllll}
\hline & Total & & Protected & \\
Areas & ha & \% & ha & h \\
\hline Trapani & $2.192,00$ & 7,2 & 257,9 & 11,8 \\
Palermo & $3.438,12$ & 11,2 & 75,01 & 2,2 \\
Messina & 448,45 & 1,5 & 28,43 & 6,3 \\
Agrigento & $3.539,16$ & 11,6 & $1.395,47$ & 39,4 \\
Caltanissetta & $3.011,56$ & 9,9 & 890,87 & 29,6 \\
Enna & 812,9 & 2,7 & 18,19 & 2,2 \\
Catania & $2.974,14$ & 9,7 & 119,4 & 4,0 \\
Ragusa & $9.155,66$ & 30,0 & $5.700,93$ & 62,3 \\
Siracusa & $4.992,07$ & 16,3 & $1.683,13$ & 33,7 \\
Sicily (a) & $30.564,06$ & 100,0 & $10.169,33$ & 33,3 \\
Italy (b) & $299.681,67$ & & $32.944,34$ & 30,9 \\
\% (a)/(b) & 10,2 & & & \\
\hline
\end{tabular}

(*) ISTAT database, Rome

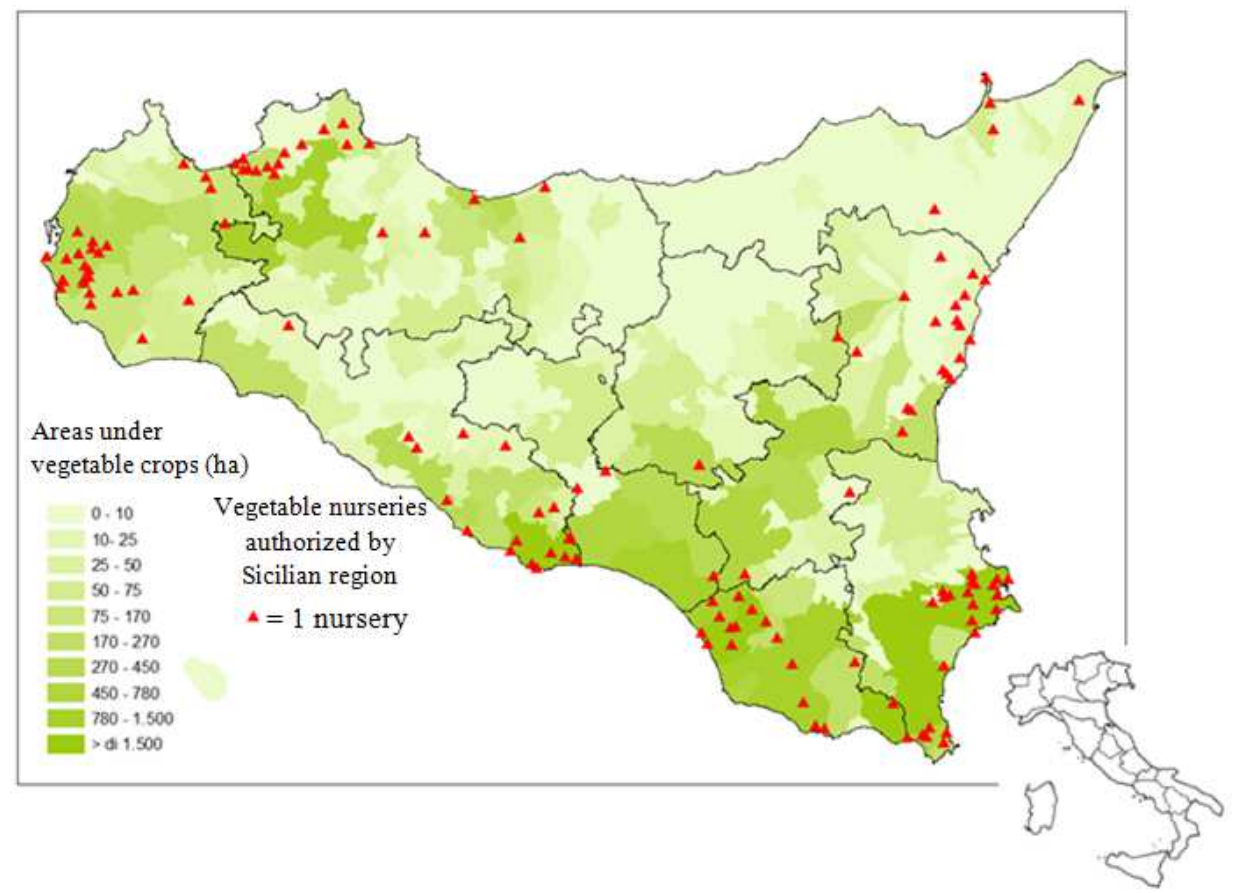

Fig. 1. Vegetable nurseries industry localization in vegetable production areas

Table 5. General characteristics of the sample of nurseries industry observed in Sicily (2013) $(*)$

\begin{tabular}{lr}
\hline Indication & Value \\
\hline Nurseries, n. & 10 \\
Parcel, n. & 100 \\
Localization, \% & 65 \\
- eastern Sicily & 35 \\
- western Sicily & \\
Vegetable plants produced/year & 8 \\
- Min, million & 10 \\
- Max, million & \\
Work (hours/ha) & 12 \\
- Min & 15 \\
- Max & \\
(*) Our elaborating &
\end{tabular}

Table 6. Results of the model for the evaluation of the availability to increase the production nursery (2013)

\begin{tabular}{llll}
\hline Variables & Factors & t-Statistic & Prob. \\
\hline Constant & $-15594,13$ & $-89,798$ & 0,0000 \\
Seeds & $1,806,164$ & 119,591 & 0,0000 \\
Farm & $-79,602$ & $-24,433$ & 0,0150 \\
Quality & 10141,1 & 139,368 & 0,0000 \\
Regulations & $-1,720,309$ & $-52,709$ & 0,0000 \\
Phytosanitary regulations & $1,030,196$ & 278,963 & 0,0048 \\
Integration & 4873,45 & 880,736 & 0,0000 \\
Adjusted R & 0,614487 & & \\
\hline
\end{tabular}

It is not difficult to suppose that plant nursery activity has expanded in those areas where vegetable is widespread. This has led the possibility to the farmer of 
finding seedlings produced on site, thus avoiding the physiological stress due the long-range transport and at the same time supporting a lower cost for the purchase of seedlings (Figs. 1 and 2). The figures clearly show that there is a certain territorial differentiation: Indeed, in addition to the proximity placement, it emerges that the density of nurseries grows in areas where protected vegetable is practiced, because it is more concerned with the repetition of crop cycles.

\section{Results of the Multivariate Model}

The empirical research and the estimation model were tested on a group of 100 observations (Table 5) relating to an equal amount of vegetable species and varieties present in the production of 10 vegetable nurseries localized in Sicily. These structures reported an average production between a minimum of 8 million seedlings/ha/year and a maximum of 10 million and degrees of activity between 12 thousand and 15 thousand hours per hectare. All nurseries have rooms for sowing and germination. The sampling is random and simple.

The processing results show an overall model variability of $61.4 \%$ (Table 6), a correct $\mathrm{R}^{2}$ not particularly high, but widely acceptable given the nature of the data and the high levels of significance associated with six variables. Even the signs of the coefficients associated with each indicator are consistent with work hypothesis. These signs attest the existence of a positive relationship between the perspectives of expansion of plant nursery production areas and some objective factors of quality, such as the vegetative and reproductive response of seedlings and the subsequent adaptation capability to transplantation, perceived as prerequisites for choice by the customer of plant nursery productions. Thus, even the type of seed (species and varieties multiplied) and the phytosanitary regulations are main factors that drive business decisions towards a broader demand for certified propagation material, in compliance with regulatory requirements (Benedetti, 1973). Vertical integration and, more generally, contract economy are essential conditions for plant nursery activity, because they allow the transfer of those innovations produced in the research world with repercussions on the commercial aspects of the plant nursery companies (local companies prefer to differentiate international hybrid species from native species; extra-local companies focus almost exclusively on international species). They may relate to the upstream propagation of seed crops, in order to obtain quality seed from health, genetic and germination point of view (between seed companies and multipliers) and downstream between multipliers and vegetable companies engaged in the production of final products (Timpanaro et al., 2013).

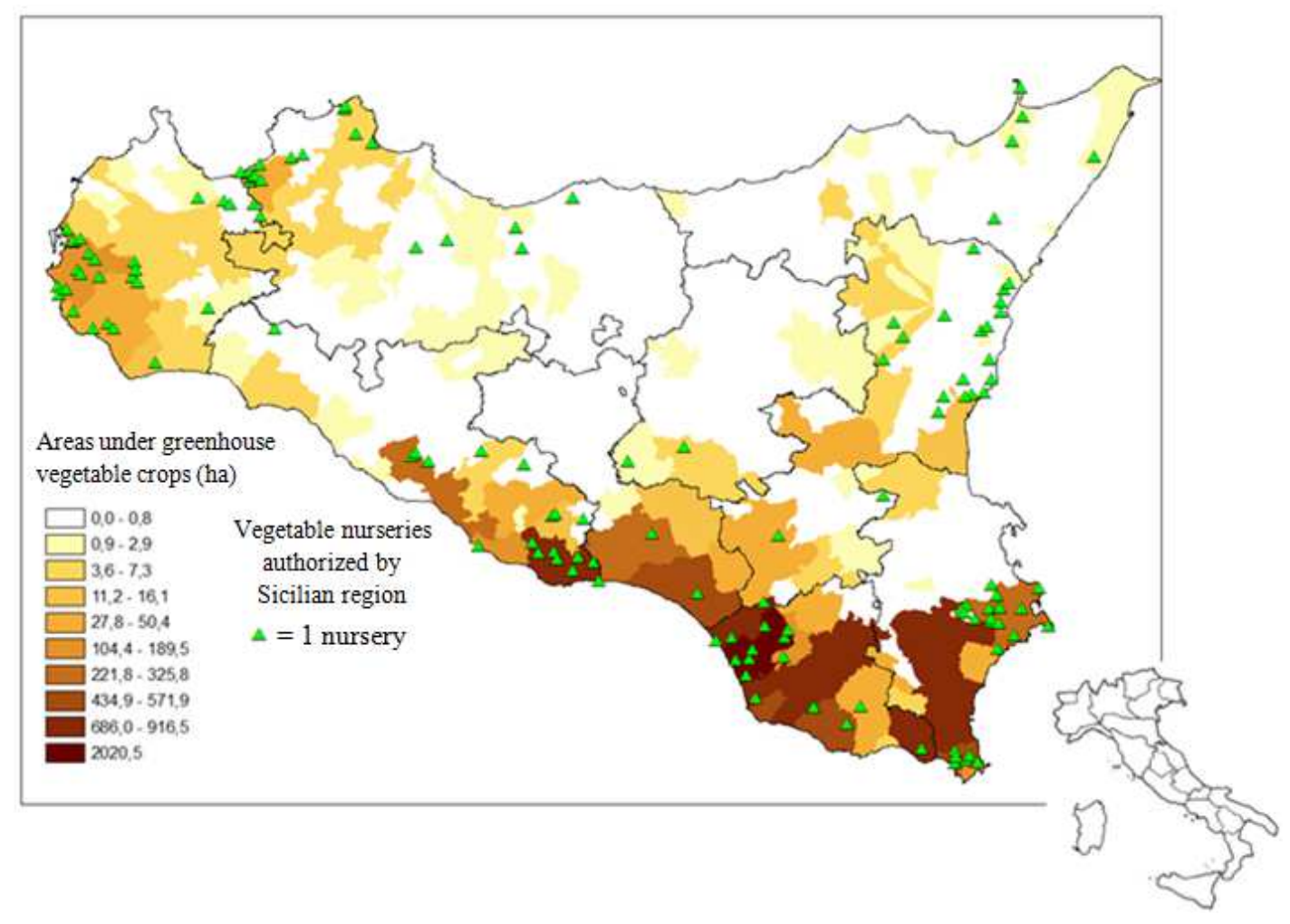

Fig. 2. Vegetable nurseries industry localization in protected vegetable production areas 
The model also shows the existence of a negative relationship between the propensity to widen nursery production and the characteristics of the companies: larger companies cannot always offer more selections at competitive prices (e.g., the royalties are fixed costs hardly compressible), while younger companies, flexible and with higher level of capitalization, appear to be more aggressive, open to innovation and change, better market-oriented and more efficiently able to expand their production base. Negative is also the tightening of the tax burden and the difficulties linked to the respect of numerous environmental legislation. To this end, an interesting analysis of the factors limiting the development of nursery companies, although in other territorial contexts.

\section{Discussion}

The very structure of the production system generates some limits activation of new production processes.Considering the nursery activities in Sicily, as in the rest of Italian regions, we can list the presence of multiple realities:

- Nursery company "strictusensu", which deals only with the multiplication of seed produced by other companies (mainly, geneticist or specialized seed companies) and focuses the "core business" on international hybrid varieties, although it does not exclude a space dedicated to the "hobby" phenomenon (FAO, 2009)

- Nursery and seed company, which provides for the creation, preservation, multiplication and marketing of hybrid and local varieties, is often linked to national and international companies

- Vegetable Company, which uses the products (seedlings) of the previous kind of companies, commissioned on request. In some cases, it holds (assigning an asset value) and self-produce, for mass selection, several vegetable "ecotypes" which are particularly appreciated on local market

- Seed Company, which has adequate expertise in the field of genetics and focuses on the development and commercialization of hybrid varieties, although it is potentially interested in the genetic traits of native species for future prospects

There is a strong duality between nursery structures that meet the requirements and recommendations contained in the relevant regulatory framework (e.g., authorizations, enrolment in the official registry, compliance with professional requirements, minimum area, guarantee of genetic, agronomic and phytosanitary compliance of material produced, mandatory and voluntary certifications, etc.) and the vegetable companies represented by the so-called "small farmers" or "non-professional" who turn themselves into producers of nursery material, fuelling a considerable inequality of the market, often to the detriment of the accredited nurseries which produce with higher production costs and prices, as well as a circulation of material not sufficiently safe from a phytosanitary and qualitative point of view. There is a dualism also between those nurserymen who deal with seed of international species and varieties and those who focus on local species and/or varieties (for which the implementation of EU directives allows special exceptions, especially if there is a real danger of genetic erosion or if the varieties have no intrinsic value for commercial production) (Elia and Santamaria, 2013; Timpanaro et al., 2014; Pulina and Timpanaro, 2012).

In the case of seed and nursery companies, the innovation that could ensure competitiveness and progress often coincides with the establishment of new varieties that meet the needs of intermediate and final customers (consumers). In turn, the private variety constitution is bound to the available resources according to the extent of the market (areas of cultivation and royalty value), to the decisions of the agricultural policy (especially with regard to the CAP and the varietal protection) and, finally, to the mechanisms for the collection of royalties. In the practice, the use of certified seed allows the collection of royalties; clearly, this is not possible using self-produced seed.

\section{Conclusion}

Ultimately, the seedlings produced by vegetable nurseries primarily meet the regional needs and only a very small part finds its place in the Italian and foreign markets, due to the inherent characteristics of the product and the structural characteristics of the vegetable nursery system. Therefore, the distribution channel mainly used by nurseries in Sicily is the direct channel, where the manufacturer has a preferential relationship with the farm (end user); only in few cases, a different distribution channel, where one or more intermediaries stand between the nursery and farm, is used.

In light of the research conducted, there are technical and territorial conditions for an expansion of the regional vegetable nursery, with positive impacts in terms of economic and social benefits as it is internationally recognized (Dehnen-Schmutza et al., 2010).

Future developments of the research will be aimed at the economic evaluation of these processes (profitable production), in order to consider an increase in the nursery areas.

\section{Acknowledgment}

The authors wish to thank the Region of Sicily for their support in the work. 


\section{Funding Information}

This study was carried out thanks to the financial support of the AssessoratoRisorseAgricole e Alimentari, Regione Sicilia "ProgettoSementieroRegionale- Analisieconomiche" (Giuseppe Timpanaro, scientific coordinator).

\section{Author's Contributions}

The study is the result of full collaboration and therefore all authors accept full responsibility for it. The actual writing of sections "Introduction", "Materials and methods", "Discussion" and "Conclusions" is attributable to Giuseppe Timpanaro; the section "Analysis of current state of plant nursery" is attributable to Arturo Urso; the section "Geo-referenced analysis" is attributable to Carlo Prato while the section "Results of the multivariate model" to Vera Teresa Foti.

\section{Ethics}

The authors declare that the work is original and is in no way influenced by associations, personal or otherorganizations or groups of pressure and was realized in full scientific freedom. Authors guarantee that no part of manuscript reporting original work was considered for publication in whole or in part elsewhere.

\section{References}

Acquaah, G., 2008. Vegetable: Principles and Practices. 4th Edn., Pearson Education, Inc.

Barbier, E.B., J. Gwatipedza, D. Knowler and S.H. Reichard, 2011. The North American horticultural industry and the risk of plant invasion. Agric. Econ., 42: $113-130$ DOI: $10.1111 / j .1574-0862.2011 .00556 . x$

Benedetti, E., 1973. Produzione e Commercio Delle Sementi. La nuova Legislazione. 1st Edn., REDA, Roma, Italy.

Bianco, V.V. and F. Pimpini, 1990. Orticoltura. Patron Ed., Bologna, Italy.

Borrough, P.A., 1986. Principles of geografic information system. Clarendon Press. Oxford, UK.

Crane, R. and C. Barahona, 1996. The Economics of Hardy Nursery Stock Production in England. 1st Edn., Spec. Stud. Agric. Econ., University of Reading, ISBN-10: 0704910438, pp: 110.

Dehnen-Schmutza, K., O. Holdenriederb, M.J. Jegerc and M. Pautassoc, 2010. Structural change in the international horticultural industry: Some implications for plant health. Scientia Horticulturae, 125: 1-15. DOI: 10.1016/j.scienta.2010.02.017
Elia, A. and P. Santamaria, 2013. Biodiversity in vegetable crops, a heritage to save: The case of Puglia region. Italian J. Agronomy, 8: e4. DOI: $10.4081 /$ ija.2013.e4

FAO, 2009. The state of the world's plant genetic resources for food and agriculture. Food Agric. Organization.

FAOSTAT, 2012. Crops production statistics. FAO Statistical.

Hardenburg, R.E., A.E. Watada and C.Y. Yang 1990. The commercial storage of fruits, vegetables and florist and nursery stocks. Agriculture Handbook, Washington.

Hodges, A.W., C.R. Hall, B.K. Behe and J.H. Dennis, 2008. Regional analysis of production practices and technology use in the U.S. nursery industry. HortScience, 43: 1807-1812.

INEA, 2013. Annuariodell'AgricolturaItaliana. Roma.

ISTAT, 2013. Electronic information system on agriculture and livestock. Italian National Statistical Institute, Rome.

Knowlera, D. and E. Barbier, 2005. Importing exotic plants and the risk of invasion: Are market-based instruments adequate? Ecological Econ., 52: 341-354.

DOI: 10.1016/j.ecolecon.2004.06.019

Malczewski, J., 1999. GIS and multicriteria decision analysis. New York, Wiley.

Malczewski, J., 2004. GIS-based land-use suitability analysis: A critical overview. Progress Planning, 62: 3-65. DOI: 10.1016/j.progress.2003.09.002

Posadas, B.C., P.R. Knight, R.Y. Coker, C.H. Coker and S.A. Langlois et al., 2008. Socioeconomic impact of automation on vegetable production firms in the Northern Gulf of Mexico Region. HortTechnology.

Pulina, P. and G. Timpanaro, 2012. Ethics, sustainability and logistics in agricultural and agri-food economics research. Italian J. Agronomy, 7: 237-246.

DOI: $10.4081 /$ ija.2012.e33

Schlimme, D.V., 1995. Marketing lightly processed fruits and vegetables. Hortscience, 30: 15-17.

Timpanaro, G., C. Bellia and V.T. Foti, 2014. Vegetable agro-biodiversity and potential conservation: Case study in Sicily. Quality Access Success, 15: 230-235.

Timpanaro, G., G. Di Vita, V.T. Foti and F. Branca, 2013. Landraces in Sicilian peri-urban horticulture: A participatory approach to brassica production system. Acta Horticulturae, 1005: 213-220.

Viani, P., 1929. Trattato di Orticoltura. 1st Edn., Battiato Editore, Catania, Italy.

Zinati, G.M., 2005. Compost in the 20th Century: A tool to control plant diseases in Nursery and vegetable crops. HortTechnology. 